\section{Assessment of Avifauna and Water Quality Parameters of Mangla Wetland, Azad Kashmir, Pakistan}

\author{
Muhammad Umar', Muhammad Arshad ${ }^{2}$, Mubashar Hussain ${ }^{1 *}$, Moazama Batool ${ }^{3}$ \\ and Muhammad Faheem Malik ${ }^{1}$
}

${ }^{1}$ Department of Zoology, Faculty of Science, University of Gujrat, Punjab, Pakistan

${ }^{2}$ Department of Zoology, Faculty of Science, University of Sargodha, Punjab, Pakistan

${ }^{3}$ Government College Women University, Sialkot, Punjab, Pakistan

\begin{abstract}
A B S T R A C T
For two consecutive years, population estimates of avifauna were carried out. Simultaneously hydrological analysis of surface water of Mangla wetland was also conducted. Bird census was carried out in the months of January and February for both years (2010 and 2011) when a large number of migratory birds visit the Mangla Wetland. The birds were counted by the Point Count Method from a fixed point and for a fixed time period in such a way that the Sun was always behind the observer. A total of 37,082 birds belonging to eight orders, 11 families, 28 genera and 37 species visited the wetland in 2010, whereas in 2011, 21,302 birds belonging to six orders, nine families, 20 genera, and 28 species. Twenty two bird species were observed to be common in both years. The most abundant species were the Black-headed gull and the great cormorant in both years. The density of population was higher in $2010\left(139.93 / \mathrm{km}^{2}\right)$ than in $2011\left(80.38 / \mathrm{km}^{2}\right)$. The level of $\mathrm{Co}^{2+} \mathrm{Cu}^{2+}, \mathrm{Fe}^{2+}, \mathrm{Mg}^{2+}, \mathrm{Mn}^{2+}$ and $\mathrm{Zn}^{2+}$ in the surface water were within the permissible limits. However, the levels of $\mathrm{Cr}^{2+}, \mathrm{Pb}^{2+}$ and $\mathrm{Cd}^{2+}$ were higher than safe limits. The concentration of these metals showed variation in different months of the year. An extensive monitoring of the lake and catchment area is suggested in order to address the threats posed by heavy metals.
\end{abstract}

\begin{tabular}{l} 
Article Information \\
Received 03 April 2017 \\
Revised 25 July 2017 \\
Accepted 30 October 2019 \\
Available online 05 March 2021 \\
Authors' Contribution \\
\hline MU conceived the idea, collected \\
samples and conducted research work. \\
MA supervised the research work. \\
MH developed manuscript and helped \\
in data analysis. MB helped in the \\
write up. MFM helped in write up \\
improvement and data analysis. \\
Key words \\
Mangla wetland, Avifauna, \\
Hydrological analysis
\end{tabular}

\section{INTRODUCTION}

W etlands are dynamic ecosystems that account for $6 \%$ of earth habitats (Maltby, 1986). They are considered as supermarkets due to the presence of wide range of flora and fauna (Mitsch and Gosselink, 2000). The habitat of wetlands is important for birds as the feeding, nesting and roosting requirements of birds are met with (Weller, 1999; Stewart, 2001). The north western part of southern Asia, Wetlands in Pakistan occupy 9.7\% area of the country, ranging from coastal mangroves to Himalayan glacial lakes (Lamsal et al., 2017). Of the 48 wetland areas in Pakistan, 19 are declared as Wetlands of International Importance (Scott, 1989). Pakistani wetlands are of importance due to their distinctiveness and diversity. An example of important wetland is Mangla Dam located in Mirpur, Azad Jammu and Kashmir (between latitude and longitude of 32 to $36 \mathrm{~N}$ and 73 to $75 \mathrm{E}$, respectively). Climate of the area is subtropical with an average maximum and minimum temperature at Mangla during September to November $\left(26^{\circ}-32{ }^{\circ} \mathrm{C}\right.$ and $14{ }^{\circ} \mathrm{C}-18{ }^{\circ} \mathrm{C}$, respectively),

\footnotetext{
* Corresponding author: dr.mubashar@uog.edu.pk 0030-9923/2021/0003-0809 \$ 9.00/0

Copyright 2021 Zoological Society of Pakistan
}

December to January $\left(12^{\circ}-16 \mathrm{C}^{\circ}\right.$ and $7^{\circ}$ to $\left.12^{\circ} \mathrm{C}\right)$ and February to April $\left(20^{\circ}-26^{\circ} \mathrm{C}\right.$ and $6^{\circ}-12{ }^{\circ} \mathrm{C}$, respectively) with an average of $1,000 \mathrm{~mm}$ rainfall (Ali et al., 2011b).

The dam was completed in 1967, the water body (12 $2^{\text {th }}$ largest dam of the world) covers an area of 26,599 ha (WAPDA, 2001). The Mangla wetland has vegetated area that provides habitat for more than 30,000 water birds such as grebes, gulls, ducks, cormorants, coots, waders, and geese (Ali et al., 2011b). Survey conducted in early 1990's identified a total of 347 species of birds in the wetlands of Pakistan which included 176 non passerine and 171 passerine species (Roberts, 1991, 1992a; Ali et al., 2011b; Khan and Ali, 2014). In 2001, another study on the avian fauna of the wetlands indicated that 336 species were present which included 115 winter visitors, 153 resident, 39 passage migrants, 15 summer visitors and 14 occasional visitors (Grimmett et al., 2008). The biodiversity in general and avian fauna specifically are under severe threat due to anthropogenic activities (Ali, 2005). The avifauna of Pakistan consists of 668 species belonging to 85 families with large number of winter visitors (Roberts, 1991, 1992a). It has been reported that $85 \%$ of the migratory fauna of Pakistan consists of ducks and waders which is higher than the resident and summer breeding bird population (Alfred, 2001). The variations 
in the water quality of wetlands such as temperature, transparency, $\mathrm{pH}$, electrical conductivity, total hardness, nitrates and phosphates determine the quantity of planktonic biomass in freshwater bodies (Mahboob and Sheri, 2001). Water pollution is a severe threat for biodiversity globally. The major causes of water pollution are: industrial effluents, and sewage waste which deposits heavy metals into water bodies (Obasohan et al., 2008). Sewage also contains a large amount of heavy metals, i.e. zinc, nickel, iron, lead, chromium, arsenic, copper, cadmium and cobalt which can accumulate in the soil and be transferred to vegetables and crops indirectly. Heavy metals are important micronutrients in low concentration like manganese, cobalt, zinc, nickel, lead and copper but their higher level poses risk for biodiversity (Nürnberg, 1983). These metals are released in industrial effluents at higher concentration levels that contaminate the water reservoir and are ultimately toxic for aquatic life (Ibok et al., 1989). Heavy metals entering into the aquatic environments can result in high accumulation and biomagnification, ultimately entering into the food chain and they can cause severe health problems by affecting the liver, kidney, muscles, and tissues of animals (Dallinger et al., 1987; McGeer et al., 2000; Xu et al., 2004; Protano et al., 2014; Xie et al., 2014). Metals like arsenic, cadmium, lead and chromium pose a severe threat to biodiversity (Hakanson, 1980; Pan and Wang, 2012). Metals like, arsenic, cadmium, lead and chromium pose a severe threat to biodiversity (Din et al., 1997). The current research work was undertaken to assess the physico-chemical parameters and concentration levels of various heavy metals in the surface water of Mangla Wetland. This water body is of special concern because it provides wintering habitat for water birds. Simultaneous with water analysis, an avifauna census during winter months (January and February) was carried out to assess the number of bird species and their population at the lake. The impact of anthropogenic activities and climate change (weathering process) was assessed by exploring diversity, abundance and species richness and evenness of avifauna visiting this water body. The study focused on working out the major factors that contribute to the declining trend of bird species at this wetland.

\section{MATERIALS AND METHODS}

The study was undertaken at Mangla wetland, situated in Mirpur, Azad Jammu and Kashmir (33.12 N, $73.39 \mathrm{E})$ across an elevation of $630 \mathrm{~m}$ and comprising an area of about $26,500 \mathrm{ha}$. The wetland is located at a distance of about $110 \mathrm{~km}$ from Islamabad.

\section{Bird estimation}

The bird census was carried out for two consecutive years 2010 and 2011 in the months of January and February as a large number of migratory birds visit the lake at that time. The reservoir was divided into five observation areas. The birds were counted by the point count method from a fixed point and for the fixed time period in such a way that the sun was always at the back of the observer. The relative abundance of each bird species was estimated by (Sutherland, 1996). The assessment of Food habits of bird species were assessed as suggested by Roberts (Roberts, 1991, 1992a). The food preference of different groups of birds was documented. Photographs were taken using field binoculars and birds were identified using keys (Ali and Ripley, 1987; Roberts, 1991, 1992). The relative abundance was calculated for each bird species so as to determine the most abundant bird species by using the terms described earlier (Bull, 1964; McCaskie, 1970). A biodiversity Index was also calculated (Shannon and Wiener, 1963).

\section{Physiochemical parameters}

Water samples were collected from the five different sites of Mangla dam during 2010 and 2011. The purpose of sampling was to determine the quality of water and variation across different months of the year. Twelve samples were collected by using 200 $\mathrm{ml}$ plastic bottles which were washed, disinfected and dried, then soaked in 5\% nitric acid for $24 \mathrm{~h}$. To restrict adsorption of heavy metals onto the wall of sampling bottles $5 \mathrm{ml}$ nitric acid was immediately added after collecting the samples (Ademoroti, 1996) and then safely transferred to laboratory. Samples were digested with $5 \mathrm{ml}$ of di-acid mixture $\left(\mathrm{HNO}_{3}: \mathrm{HClO}_{4}\right.$ : 9: 4 ratio) on a hot plate and filtered by Whatman No. 42 filter paper and made up the volume to $50 \mathrm{ml}$ by adding distilled water for heavy metal analysis (Kar et al., 2008). Digested samples were placed in prewashed polythene bottles. Analytical grade reagents were used throughout the processing period. Various standards of heavy metals were prepared from certified standard stock solution ( $\mathrm{ppm}$ ) by using distilled water. These standards were used to obtain a calibration curve on an Atomic Absorption Spectrophotometer (Shimadzu AA-6300). Water samples were analyzed for heavy metals i.e. $\mathrm{Cd}, \mathrm{Co}, \mathrm{Cr}, \mathrm{Cu}, \mathrm{Fe}, \mathrm{Mn}, \mathrm{Ni}, \mathrm{Pb}$, Zn (McGeer et al., 2000; Scott, 1989) by the process of Atomic Absorption Spectrophotometry. One-way ANOVA was applied to analyze the variation across time (Steel and Torrie, 1980). 


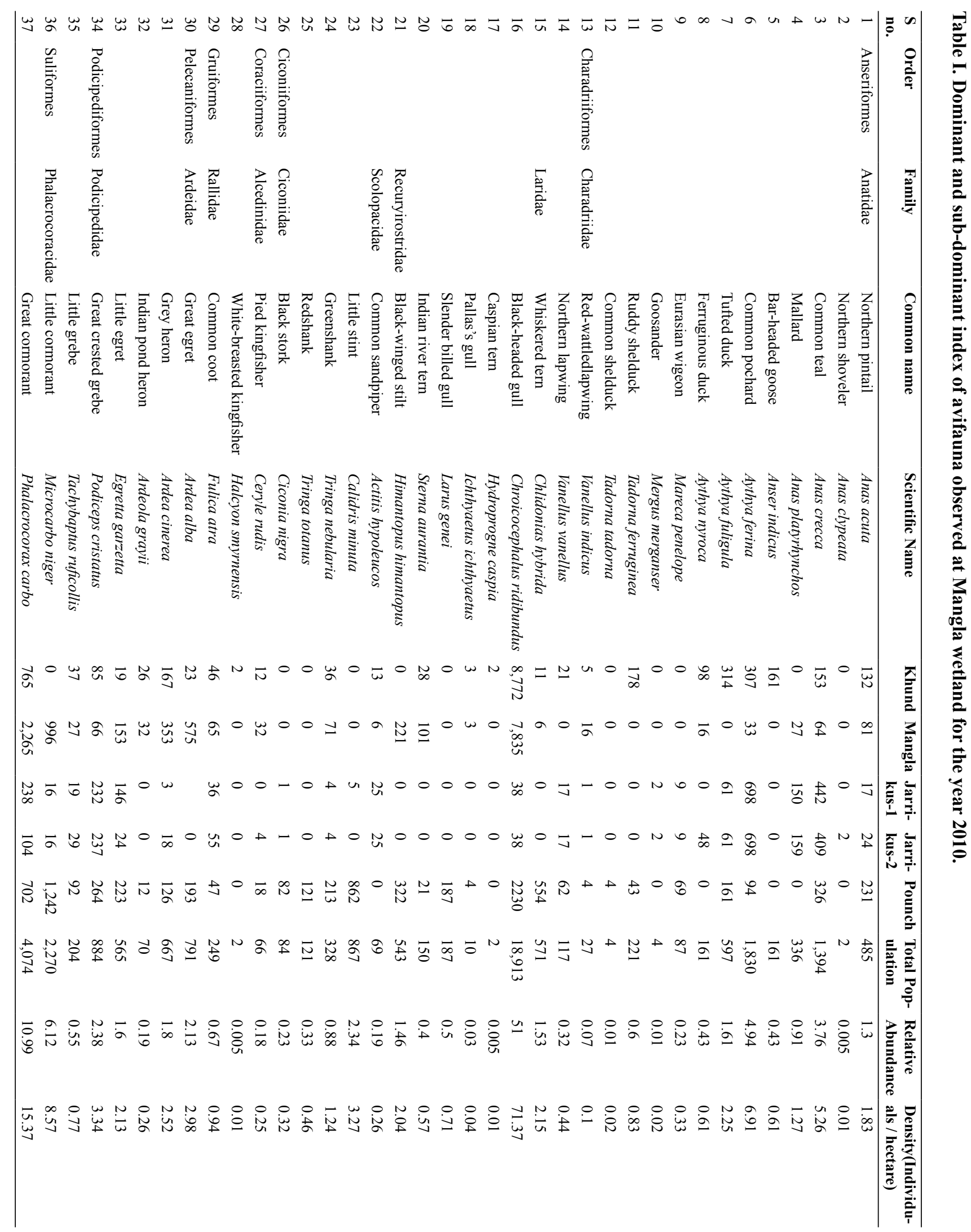




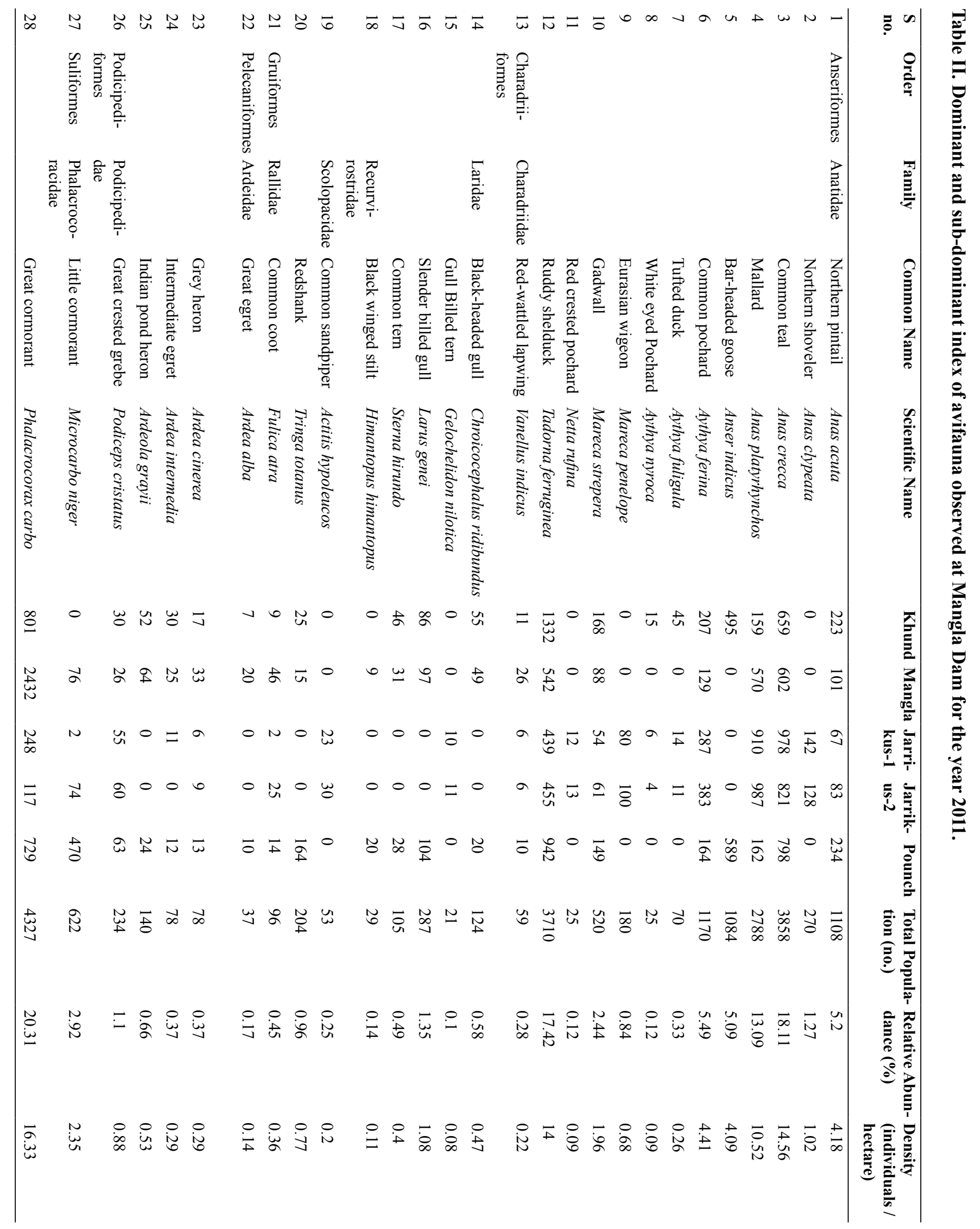




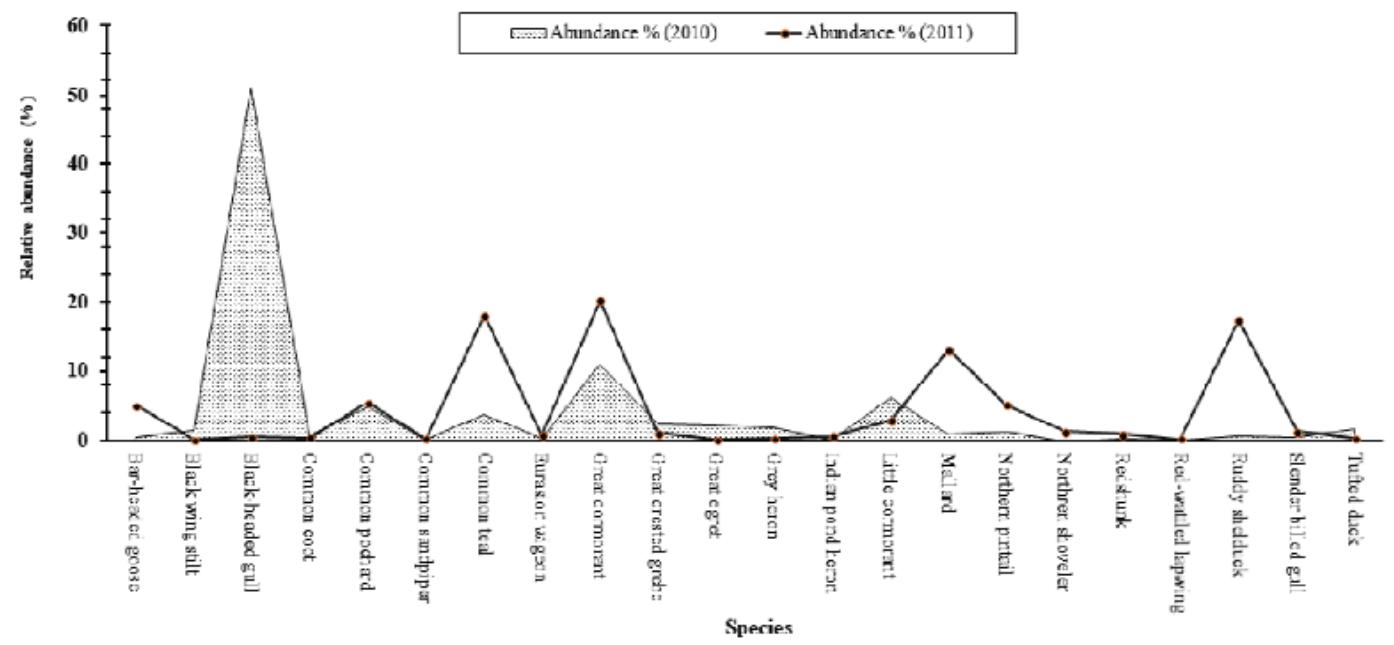

Fig. 1. Relative abundance (\%) of common bird species at Mangla wetland recorded during 2010 and 2011.

Table III. Summary of different analysis of data recorded from Mangla Dam during the year 2010 and 2011.

\begin{tabular}{lll}
\hline Parameters & \multicolumn{2}{c}{ Year } \\
\cline { 2 - 3 } & $\mathbf{2 0 1 0}$ & $\mathbf{2 0 1 1}$ \\
\hline Area surveyed (ha) & $26,500 \mathrm{ha}$ & 26,500 ha \\
Total population & 37,082 & 21,302 \\
Number of species & 37 & 28 \\
Census Index & $139.93 / \mathrm{km}^{2}$ & $80.38 / \mathrm{km}^{2}$ \\
Dominant species & Black Headed Gull $(51.00 \%$ relative abundance) & Great cormorant $(20.31 \%$ relative abundance $)$ \\
Sub-dominant species & Great Cormorant $(10.99 \%$ relative abundance $)$ & Common teal $(18.11 \%$ relative abundance $)$ \\
\hline
\end{tabular}

\section{RESULTS}

A total of 37,082 birds belonging to 37 species, 26 genera, 12 families and eight orders in 2010 whereas in $2011,21,302$ birds were counted that belonged to 28 species, 20 genera, 10 families and six orders (Tables I and II). The relative abundance of each bird species was calculated (Tables I and II). The black- headed gull was the most abundant species in 2010, while in 2011, the most abundant species was great cormorant. In 2010, the dominant and subdominant bird species were black-headed gull $(51.00 \%)$ and great cormorant (10.99 \%) (Table III). However, the dominant and subdominant bird species in 2011 were great cormorant $(20.31 \%)$ and common teal (18.11\%), respectively (Table III). The least abundant bird species were Northern shoveler white-breasted kingfisher and Caspian tern, whose relative abundance was even less than 0.01 . The total area of the lake $(26,500 \mathrm{ha})$ was determined by using GIS techniques (Table III). The density of birds at the site was higher in $2010\left(140 / \mathrm{km}^{2}\right)$ than to $2011\left(80 / \mathrm{km}^{2}\right)$.
Twenty two species were seen in both years including bar-headed goose, common pochard, common teal, eurasian wigeon, mallard, northern pintail, northern shoveler, ruddy shelduck, Tufted duck, etc. (Fig. 1). In 2010, 37 bird species were recorded which included abundant (14), very common (11), very abundant (05), and rare (05) species, common (01) and fairly common (01) (Fig. 4). In 2011, however, 27 bird species were recorded including very abundant (04), abundant (09), very common (09) and common (05) species (Fig. 4).

Birds feeding preferences were also determined. Most birds were carnivorous $(68.88 \%$; insects, mollusks, crustaceans, fish, and frogs) followed by omnivorous (24.44\%; leaves, shoots, seeds, submerged vegetation, insects, insect larvae, small beetles and worms) and herbivorous $(6.66 \%$; shoots of plants and vegetation in water) birds (Figs. 2 and 3). In 2010, the number of bird species observed at different sites include Pounch (30), Khund (26), Mangla (23), Jarrikus-1 (22) and Jarrikus-2 (23). However, a different pattern was observed in 2011 i.e. Pounch (21), Khund (21), Mangla (20), Jarrikus-1 
(20), and Jarrikus-2 (19) (Fig. 5). Forty three bird species included 25 winter visitors, 13 resident, two double passage migrants, one summer breeders and two irregular yearround visitors were recorded during 2010-2011 (Fig. 6).

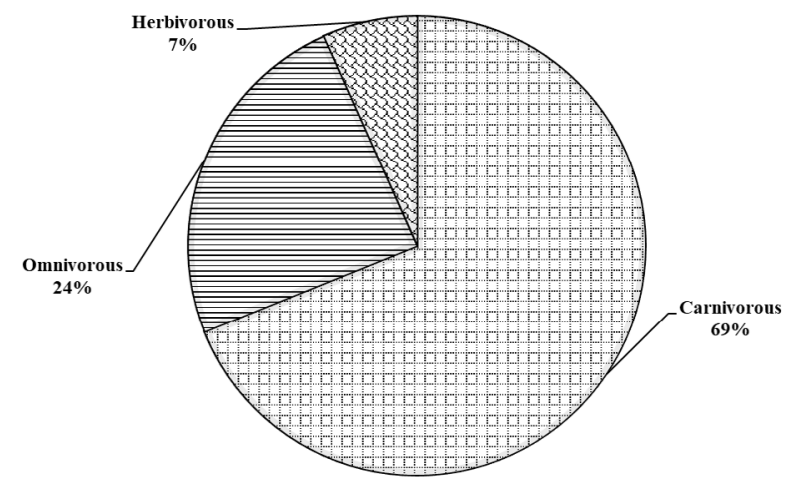

Fig. 2. Distribution of bird species into different feeding guilds at Mangla Dam in winter 2010.

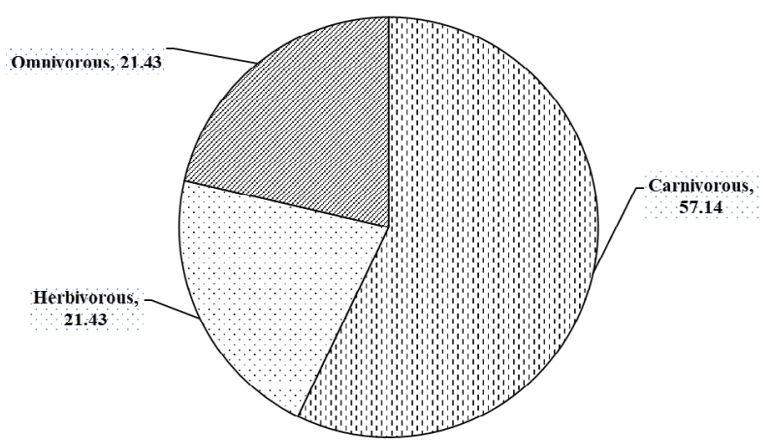

Fig. 3. Distribution of bird species into different feeding guilds at Mangla Dam in winter 2011.

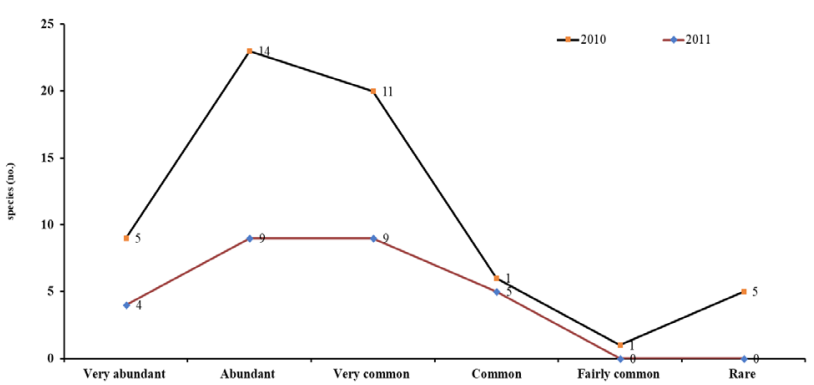

Fig. 4. Species status and their relative abundance at Mangla Dam for year 2010 and 2011.

The concentration level of heavy metals in the water samples from Mangla Lake followed the decreasing trend: $\mathrm{Cr}>\mathrm{Fe}>\mathrm{Co}>\mathrm{Zn}>\mathrm{Pb}>\mathrm{Ni}>\mathrm{Cu}>\mathrm{Cd}>\mathrm{Mn}$. Minimum values for $\mathrm{Cr}$, and $\mathrm{Cd}$ was recorded in September. However, the maximum levels for $\mathrm{Co}, \mathrm{Mn}, \mathrm{Ni}$ and $\mathrm{Cu}$ was found in
August, April, October and June (Table IV). The lowest range for $\mathrm{Zn}, \mathrm{Pb}$ and $\mathrm{Fe}$ was observed in the months of January (0.0260), November (0.0181) and August (0.0321). Monthly variation in the concentration of metals showed significant differences (Table V). However, temporal variations between sampling stations were nonsignificant $(\mathrm{p}>0.05)$.

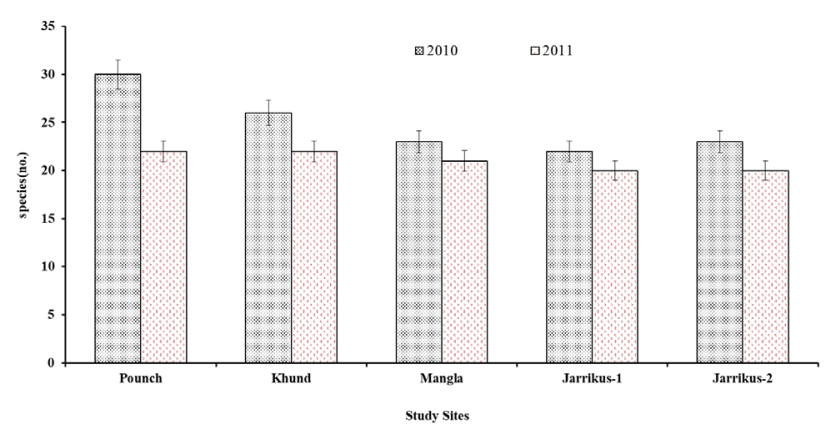

Fig. 5. Number of bird species recorded form different sites of Mangla dam during 2010 and 2011.

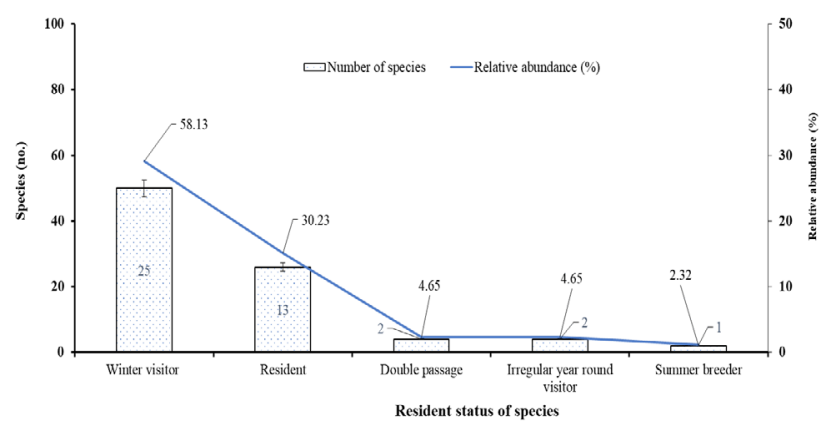

Fig. 6. Relative abundance and resident status of avifauna observed at Mangla dam during 2010 and 2011.

\section{DISCUSSION}

Migration in birds is a litmus test for the environmental quality and healthy bird populations that indicate healthy habitats and vice versa. One third of the endangered bird species choose their habitat near or in wetland areas. It is estimated that $42 \%$ of the bird populations of the migratory water birds have shown declining trend in the flyways (Ali et al., 2011a). Mangla Dam provides staging and wintering area for many water bird species. Many researchers reported different abundance of the species observed at Mangla Wetland (Ali et al., 2011b; Grimmett et al., 2013; Khan and Ali, 2014). Roberts $(1991,1992)$ has reported 347 bird species at the lake area out of which 176 were non passerines (Khan and Ali, 2014; Ali et al., 2011b). In 2001, 336 bird species (Grimmett et al., 2008) whereas in 2006, 141 bird species were observed at Mangla dam. 
Table IV. Heavy Metal concentration recorded at different sites of Mangla dam wetland during 2010 - 2011.

\begin{tabular}{|c|c|c|c|c|c|c|c|c|c|}
\hline \multicolumn{10}{|c|}{ Metals (mg/liter) } \\
\hline Sampling month & $\mathrm{Cr}$ & Co & Mn & $\mathbf{N i}$ & $\mathrm{Cu}$ & Zn & $\mathbf{P b}$ & $\mathbf{F e}$ & Cd \\
\hline October, 2010 & 0.1100 & 0.0620 & 0.0032 & 0.0222 & 0.0112 & 0.0288 & 0.0199 & 0.0709 & 0.0103 \\
\hline November, 2010 & 0.1518 & 0.0510 & 0.0045 & 0.0210 & 0.0118 & 0.0320 & 0.0181 & 0.0953 & 0.0111 \\
\hline December, 2010 & 0.1629 & 0.0672 & 0.0048 & 0.0204 & 0.0101 & 0.0381 & 0.0186 & 0.1029 & 0.0119 \\
\hline January, 2011 & 0.1642 & 0.0560 & 0.0051 & 0.0124 & 0.0142 & 0.0260 & 0.0210 & 0.0910 & 0.0108 \\
\hline February, 2011 & 0.1272 & 0.0671 & 0.0048 & 0.0135 & 0.0155 & 0.0281 & 0.0221 & 0.1017 & 0.0113 \\
\hline March, 2011 & 0.1250 & 0.0512 & 0.0053 & 0.0133 & 0.0155 & 0.0406 & 0.0216 & 0.1081 & 0.0115 \\
\hline April, 2011 & 0.1315 & 0.0501 & 0.0056 & 0.0139 & 0.0154 & 0.0502 & 0.0223 & 0.1100 & 0.0129 \\
\hline May, 2011 & 0.1312 & 0.0274 & 0.0037 & 0.0141 & 0.0176 & 0.0601 & 0.0221 & 0.0599 & 0.0140 \\
\hline June, 2011 & 0.1283 & 0.0294 & 0.0028 & 0.0150 & 0.0183 & 0.0605 & 0.0201 & 0.0460 & 0.0176 \\
\hline July, 2011 & 0.1290 & 0.0940 & 0.0023 & 0.0139 & 0.0102 & 0.0583 & 0.0199 & 0.0440 & 0.0129 \\
\hline August, 2011 & 0.1209 & 0.0990 & 0.0022 & 0.0107 & 0.0038 & 0.0670 & 0.0212 & 0.0321 & 0.0112 \\
\hline September, 2011 & 0.1092 & 0.0419 & 0.0033 & 0.0101 & 0.0031 & 0.0681 & 0.0182 & 0.0652 & 0.0041 \\
\hline Mean & 0.1326 & 0.0580 & 0.0039 & 0.0150 & 0.0122 & 0.0464 & 0.0204 & 0.0772 & 0.0116 \\
\hline $\mathrm{SD}$ & 0.01809 & 0.0220 & 0.0011 & 0.0039 & 0.0049 & 0.0159 & 0.0015 & 0.0276 & 0.0030 \\
\hline Min & 0.1092 & 0.0274 & 0.0022 & 0.0101 & 0.0031 & 0.0260 & 0.0181 & 0.0321 & 0.0041 \\
\hline Max & 0.1642 & 0.0990 & 0.0056 & 0.0222 & 0.0183 & 0.0681 & 0.0223 & 0.1100 & 0.0176 \\
\hline WHO limit & 0.05 & 1.0 & 0.05 & 0.05 & 0.05 & 0.10 & 0.01 & 1.00 & 0.005 \\
\hline NEQS Standards & 0.05 & 0.05 & 0.05 & 0.02 & 2.00 & 5.00 & 0.01 & 5.00 & 0.01 \\
\hline
\end{tabular}

Table V.Analysis of variance on heavy metal concentration in water of Mangla Dam during 2010-2011.

\begin{tabular}{llllll}
\hline & $\begin{array}{l}\text { Sum of } \\
\text { Squares }\end{array}$ & $\begin{array}{l}\text { df } \\
\text { Square }\end{array}$ & $\begin{array}{l}\text { Mean } \\
\text { Sq }\end{array}$ & Sig. \\
\hline Between Groups (Cr) & .007 & 11 & .001 & 46.072 & .000 \\
Between Groups (Co) & .010 & 11 & .001 & 199.805 & .000 \\
Between Groups (Mn) & .000 & 11 & .000 & 72.694 & .000 \\
Between Groups (Ni) & .000 & 11 & .000 & 156.106 & .000 \\
Between Groups (Cu) & .001 & 11 & .000 & 1915.210 & .000 \\
Between Groups ( $\mathrm{Zn})$ & .006 & 11 & .001 & 1456.612 & .000 \\
Between Groups (Pb) & .000 & 11 & .000 & 86.398 & .000 \\
Between Groups (Fe) & .017 & 11 & .002 & 141.336 & .000 \\
Between Groups (Cd) & .000 & 11 & .000 & 177.670 & .000 \\
\hline
\end{tabular}

In 2007, field survey data reported a total of bird 149 species and number of species observed at different lakes varied i.e. the Chashma (126), Nammal (115), Rangpur (110), and Uchalli (103) (Ali et al., 2007). In a survey conducted during 2008-2009 at Kallar Kahar lake, A total of 86 bird species belonging to 16 orders and 36 families were recorded. In our study, winter count of bird species were 37 in 2010 whereas 28 in 2011. The lower number of bird species in the subsequent year (2011) may owe to the human and livestock activities due to Mangla dam upraising. Earlier research work reported that the trend of waterfowl species decline due to increase in human and livestock activities (Khan, 1992).Similarly, Avifauna reported at Jiwani wetland Pakistan showed 120 (Roberts, 1991, 1992b), 101 (Grimmett et al., 2008) and 84 bird species (Mirza and Wasiq, 2007). Declining trend of birds were reported from Taunsa Barriage (Roberts, 1991; Mirza and Wasiq, 2007; Mahboob, 2009). Such variations in the population statistics may be attributed to different timings and duration of the surveys. However, earlier reported that it is difficult to assess the factors responsible for the change of population (Chaudhry, 2002). The other causes of decline of avifauna may be due the degradation of habitat due to anthropogenic activities, use of some species as game birds and illegal hunting and poaching, agricultural and industrial pollution, heavy metal poisoning may be other important causes of decline in bird's diversity (Umar et al., 2018). The reason for such a difference in number of species visiting this wetland may be owing to the fact that lakes have suffered degradation mainly due to anthropogenic activities and partial or local migration of birds. The population trends of waterfowl species declined due to increase in human and livestock 
activities. Water birds use different types of habitats at different times of their lifecycle. But it is difficult to assess the factors responsible for the decreasing trend of change of population. The food chain has an important link with the diversity and distribution of birds i.e. birds feed on insects, other small animals and seeds, fruits etc. We reported relatively higher abundance of carnivore bird species including insectivores followed by omnivore and herbivore species during winter sampling. The birds keep on moving towards other wetlands in Pakistan in search of resources. Trends in water bird population could be the indicator of changes in ecological resources (Ali, 2005). Ducks were seen in greater number at Mangla Lake due to its abundant resources and high carrying capacity. In our study, most frequent populations observed in both years were black-headed gull, common pochard, common teal, eurasian wigeon, mallard, northern pintail, northern shoveler, ruddy shelduck, tufted duck which constituted major abundance of the species inhabiting Mangla wetland. Black headed gull is migratory and winters visitor to Indian subcontinent including Pakistan which occupies variety of habitats, including urban areas (Balmer et al., 2013). A study in 2006, reported 1182 individuals from the Mangla Lake (Ali et al., 2011b). We reported black-headed gull was dominant bird species in 2010 with relative abundance of about $50 \%$ whereas drastically lower abundance was recorded during 2011 (124 individuals). Such variations in population decline may be due to population shift towards Uchhali complex owing to restoration of resources. Anthropogenic stress increases the short-term variability of ecological communities (Hillebrand et al., 2008). However, lower number of individuals of black-headed gull were also noted at Taunsa Barriage (Ali et al., 2011a). Common teal, the most abundant game bird at major wetlands of Pakistan, widely hunted. It lives in flocks of about 200 birds. We reported common teal as abundant species (3858 individuals) in 2011 whereas significantly lower population (1349 individuals) were recorded in 2010. Mallard, a winter migrant, also showed variations in its population (336 in 2010 and 2788 in 2011). The maximum population (600 individuals) was recorded at Drigh Lake in Sindh (Gabol et al., 2005) whereas 729 individuals were reported at Uchhali complex (Ali, 2005). Due to readily adaptable and high tolerance for disturbance, it adjusts in a variety of breeding and wintering habitats (Ali, 2005). Only a few individuals mallard were as observed in Muzaffarabad division during a three year study (Awan et al., 2000). In our study, northern shoveler was the least abundant bird species which prefers the stagnant and muddy water. However, earlier it was reported that it was the abundant winter visitor at Mangla dam (Ali et al., 2011b). The decrease in the population of this bird could be due to occupation of the habitat at Mangla Lake by other bird species which may have migrated from other wetlands. Similarly, higher number of population of bird was recorded at Drigh Lake in 2000 (Gabol et al., 2005), Kallar Kahar Lake and also at the Uchhali Complex in 2011. White-breasted kingfisher was reported rare in our study which was also resident bird species in Muzaffarabad (Awan et al., 2000). White breasted kingfisher occupied the status of common bird at Trimmu dam and also fairly common at Mangla Dam (Ali et al., 2011a). Migration in birds to a specific habitat is an excellent indicator for the environmental quality, thus, healthy bird populations indicate healthy habitats and vice versa. We assessed water quality parameters of Mangla Dam which indicated the presence of heavy metals at levels lower than WHO limits except $\mathrm{Cr}, \mathrm{Cd}$ and $\mathrm{Pb}$. Mangla Dam provides staging and wintering area for various water bird species. The productivity of fresh water ecosystem in the form of planktonic biomass is regulated by factors such as temperature, $\mathrm{pH}$, transparency, total hardness, etc. (Mahboob, 2009). Higher level of metal ions creates turbidity and discoloration of lake water (Trivedi, 1992). Except $\mathrm{Cr}, \mathrm{Pb}$ and $\mathrm{Cd}$ all other metals were within the safe limit in our study. $\mathrm{Cr}, \mathrm{Cd}$ and $\mathrm{Pb}$ having relatively higher concentration at Mangla Lake (Gulfraz et al., 2001). It may be due to the addition of untreated municipal waste from poultry farms and geological weathering taking place in the catchment areas. The seasonal variation in water level and quality modifies the population density of both animal and plant species (Odum and Barrett, 1971). The higher level of Cr was observed in January-2011. Similar results were reported for the same water body and Rawal Lake (Gulfraz et al., 2001). Cr with higher levels in the reservoir in January may be attributed to the low water level and metal deposition. However, low metal level was noted in September as water inflow and outflow was higher which did not allow the metal deposition. Cr concentration in higher quantities in the diet decreases the muscle fat in birds and increases protein deposition (Ward et al., 1995).

Physical, chemical and biological processes occur permanently in water bodies and should be considered to explain the inorganic elements and heavy metals concentrations (Narayanan and Vijayan, 2007). Entry of heavy metals in wastewater into aquatic system through leaching of rocks, airborne dust, forest fires and vegetation imposes serious environmental problems ultimately adversely affecting biodiversity (Fernandez-Leborans and Herrero, 2000; Ogoyi et al., 2011). Lead concentration was higher than permissible limits in the month of January to May. Similarly, higher concentration level of Lead was reported from Mangla (Iqbal et al., 2006) and Kallar Kahar lakes (Gulfraz et al., 2001). The higher 
level could be due to snow fall and rainy season by which atmospheric Lead comes to the soil and ultimately enters into this wetland. It causes several diseases in birds such as anemia, weight loss as indicated by green watery feces (Redig et al., 1980). It also affects circulatory system, nervous system, kidneys, biochemical and behavioral changes in animals (Scheuhammer and Templeton, 1998). The level of Cadmium was not within safe limits. The higher value was recorded from March to June. Similar trend was observed at from Manchar Lake, Kallar Kahar, respectively (Gulfraz et al., 2001; Iqbal et al., 2006). This higher level could be due to emission of Cadmium from natural resources to environment by volcanic activities, weathering of rocks and sea spray or it may be due to anthropogenic activities such as burning of fossil fuels, industrial processes, municipal effluents, metal extraction, and phosphate fertilizers and also from the uncontrolled open burning of wastes. This atmospheric cadmium comes to ground with rain and snow in winter and ultimately into lake water. As cadmium, the metal toxicant exists in the environment naturally and industrially, that enters into biological system via food, soil and water. It causes the reproductive toxicity in birds and decline in egg production (Rahman et al., 2007). The observed values of Mn, Co, Ni, $\mathrm{Fe}, \mathrm{Zn}$ and $\mathrm{Cu}$ indicated that these metals occur under safe limits. Anthropogenic activities also affect concentration level of heavy metals and inorganic elements (Baeyens et al., 1998).

The present study infer that the Mangla Dam serves as an important reservoir for both resident and migratory bird species. During the study, it was observed that the bird population monitoring, habitat assessment and launching bird protection campaigns should be implemented. Water quality parameters and availability of nutrients need to be assessed on regular basis. Commercial fish farming and fish harvesting may have negative impact on food web of this reservoir, thus, research activities focusing on habitat management and species conservation need to be conducted.

\section{CONCLUSION}

Mangla wetland avifauna population estimation recorded a total of 37,082 birds belonging to 37 species and six orders visiting the wetland in 2010 whereas 28 bird species belonging to eight orders with a population of 21,302 birds were recorded in 2011. In surface water analysis, the level of heavy metals $\left(\mathrm{Co}^{+2}, \mathrm{Cu}^{+2}, \mathrm{Fe}^{+2}, \mathrm{Mg}^{+2}\right.$, $\mathrm{Mn}^{+2}$ and $\mathrm{Zn}^{+2}$ ) were found to be within the permissible limits whereas levels of $\mathrm{Cr}^{+2}, \mathrm{~Pb}^{+2}$ and $\mathrm{Cd}^{+2}$ were higher than the safe limits. The study emphasized on the extensive monitoring of this wetland of International Importance and catchment area in order to address the threats posed by heavy metals.

\section{Statement of conflict of interest}

The authors declare there is no conflict of interest.

\section{REFERENCES}

Ademoroti, C., 1996. Standard methods for water and effluents analysis. Ibadan: Foludex Press Ltd., 3: $29-118$.

Alfred, J.R.B., Kumar, A., Tak, P.C. and Sati, J.P., 2001. Waterbirds of Northern India. India Occas. Pap. No. 190, 1st edn. , Zoological Survey of India, Kolkata.

Ali, S. and Ripley S.D., 1987. Birds of India and Pakistan. Oxford University Press. New. Delhi.

Ali, Z., 2005. Ecology, distribution and conservation of migratory birds at Uchalli Wetlands Complex, Punjab, Pakistan. University of Punjab.

Ali, Z., Ahmed, S., Khan, M. and Akhter, M., 2007. Recent records of globally endangered whiteheaded duck Oxyura leucocephala in Pakistan. J. Anim. Pl. Sci., 17: 36-40.

Ali, Z., Bibi, F., Shelly, S., Qazi, A. and Khan, A., 2011a. Comparative avian faunal diversity of Jiwani coastal wetlands and taunsa barrage wildlife sanctuary, Pakistan. J. Anim. Pl. Sci., 21: 381-387.

Ali, Z., Shelly, S., Bibi, F., Joshua, G., Khan, A., Khan, B. and Akhtar, M., 2011b. Peculiarities of Mangla reservoir: Biodiversity with sustainable use options. J. Anim. Pl. Sci., 21: 372-380.

Awan, M.N., Awan, M.S. and Khawaja Basharat Ahmed, A.A., 2000. A preliminary study on distribution of avian fauna of Muzaffarabad-Azad Jammu and Kashmir, Pakistan. Order, 01.

Baeyens, W., Elskens, M., Gillain, G. and Goeyens, L., 1998. Biogeochemical behaviour of $\mathrm{Cd}, \mathrm{Cu}, \mathrm{Pb}$ and $\mathrm{Zn}$ in the scheldt estuary during the period 19811983. Trace metals in the westerschelde estuary: a case-study of a polluted, partially anoxic estuary. Springer. https://doi.org/10.1007/978-94-0173573-5 2

Balmer, D.E.E., Gillings, S., Caffrey, B., Swann, R., Downie, I. and Fuller, R., 2013. Bird Atlas 200711: the breeding and wintering birds of Britain and Ireland. BTO Thetford.

Bull, J.L., 1964. Birds of the New York area. Harper and Row.

Chaudhry, A.A., 2002. White-headed Duck Survey in Pakistan: 2002. Wetlands International.

Dallinger, R., Prosi, F., Segner, H.and Back ,H., 1987. 
Contaminated food and uptake of heavy metals by fish: a review and a proposal for further research. Oecologia, 73: 91-98. https://doi.org/10.1007/ BF00376982

Din, M., Hussain F., Ashraf N., Hussain S., Rana N.M., Anwar K., Dil A.S. and Sami, Z., 1997. The quality assessment of drinking water supplied to Islamabad. Proceedings of the NSMTCC 97, Environment Pollution, February 24-26, 1997, Islamabad, Pakistan, pp. 453-458.

Fernandez-Leborans, G. and Herrero, Y.O., 2000. Toxicity and bioaccumulation of lead and cadmium in marine protozoan communities. Ecotoxicol. environ. Safe., 47: 266-276. https://doi.org/10.1006/ eesa.2000.1944

Gabol, K., Khan, M. and Ghalib, S., 2005. Some observation on the birds and physio-chemical parameters of Hadero Lake Sindh. J. nat. Hist. Wildl, 4: 121-125.

Grimmett, R., Inskipp, C. and Inskipp, T., 2013. Birds of the Indian Subcontinent: India, Pakistan, Sri Lanka, Nepal, Bhutan, Bangladesh and the Maldives. Bloomsbury Publishing.

Grimmett, R., Roberts, T.J., Inskipp, T. and Byers, C., 2008. Birds of Pakistan. A and C Black.

Gulfraz, M., Ahmad, T.and Afal, H., 2001. Concentration levels of heavy and trace metals in the fish and relevant water from Rawal and Mangla lakes. $J$. biol. Sci., 1: 414-416. https://doi.org/10.3923/ jbs.2001.414.416

Hakanson, L., 1980. An ecological risk index for aquatic pollution control. A sedimentological approach. Water Res., 14: 975-1001. https://doi. org/10.1016/0043-1354(80)90143-8

Hillebrand, H., Bennett, D.M. and Cadotte, M.W., 2008. Consequences of dominance: a review of evenness effects on local and regional ecosystem processes. Ecology, 89: 1510-1520. https://doi. org/10.1890/07-1053.1

Ibok, U., Udosen, E. and Udoidiong, O., 1989. Heavy metals in fishes from some streams in Ikot Ekpene area of Nigeria. Nig. J. Tech. Res, 1: 61-68.

Iqbal, M., Ashraf, M., Jamil, A. and Ur-Rehman, S., 2006. Does seed priming induce changes in the levels of some endogenous plant hormones in hexaploid wheat plants under salt stress? J. Integr. Pl. Biol., 48: 181-189. https://doi.org/10.1111/ j.1744-7909.2006.00181.x

Kar, D., Sur, P., Mandai, S., Saha, T. and Kole, R., 2008. Assessment of heavy metal pollution in surface water. Int. J. environ. Sci. Technol., 5: 119-124. https://doi.org/10.1007/BF03326004
Khan, A., 1992. Activity budgets and population analysis of waterfowl and ecosystem management of Sultan marshes (Turkey). Ph. D. thesis presented to the Middle East Technical University Ankara.

Khan, B. and Ali, Z., 2014. Assessment of birds' fauna, occurrence status, diversity indices and ecological threats at Mangla dam, ajk from 2011 to 2014. J. Anim. Pl. Sci. 25: 397-403.

Lamsal, P., Atreya, K., Pant, K.P. and Kumar, L., 2017. People's dependency on wetlands: South Asia perspective with emphasis on Nepal. Wetland Science. Springer. https://doi.org/10.1007/978-81322-3715-0 21

Mahboob, S. and Sheri, A., 2001. Influence of fertilizers and artificial feed on the seasonal variation of planktonic life in fish. Pak. J. biol. Sci, 8: 125-132.

Maltby, E., 1986. Wetlands of the world, London. pp. 12-17.

McCaskie, G., 1970. Shorebird and waterbird use of the Salton Sea. Calif. fish game, 56: 87-95.

McGeer, J.C., Szebedinszky, C., McDonald, D.G. and Wood, C.M., 2000. Effects of chronic sublethal exposure to waterborne $\mathrm{Cu}, \mathrm{Cd}$ or $\mathrm{Zn}$ in rainbow trout. 1: Iono-regulatory disturbance and metabolic costs. Aquat. Toxicol., 50: 231-243. https://doi. org/10.1016/S0166-445X(99)00105-8

Mirza, Z. and Wasiq, H., 2007. A field guide to birds of Pakistan. Bookland. Lahore.

Mitsch, W. and Gosselink, J., 2000. The value of wetlands: importance of scale and landscape setting. Ecol. Econ., 35: 25-33. https://doi.org/10.1016/ S0921-8009(00)00165-8

Narayanan, S.P. and Vijayan, L., 2007. Status of the colonial breeding waterbirds in Kumarakom Heronry in Kerala, Southern India. Podoces, 2: 2229.

Nürnberg, H., 1983. Investigations on heavy metal speciation in natural waters by voltammetric procedures. Fresenius' Z. Anal. Chem., 316: 557565. https://doi.org/10.1007/BF00492265

Obasohan, E., Oronsaye, J.and Eguavoen, O., 2008. A comparative assessment of the heavy metal loads in the tissues of a common catfish (Clarias gariepinus) from Ikpoba and Ogba Rivers in Benin City, Nigeria. Nigeria. Afr. Sci., 9: 13-23.

Odum, E.P. and Barrett, G.W., 1971. Fundamentals of ecology. Saunders, Philadelphia.

Ogoyi, O.D., Mwita, C.J., Nguu, E.K. and Shiundu, P.M., 2011. Determination of heavy metal content in water, sediment and microalgae from Lake Victoria, East Africa. The Open environ. Engin. J., 4: 156-161. https://doi.org/10.2174/1874829501104010156 
Pan, K. and Wang, W.-X., 2012. Trace metal contamination in estuarine and coastal environments in China. Sci. Total Environ., 421: 3-16. https://doi. org/10.1016/j.scitotenv.2011.03.013

Protano, C., Zinnà, L., Giampaoli, S., Spica, V.R., Chiavarini, S. and Vitali, M., 2014. Heavy metal pollution and potential ecological risks in rivers: a case study from southern Italy. Bull. environ. Contam. Toxicol., 92: 75-80. https://doi. org/10.1007/s00128-013-1150-0

Rahman, M.S., Sasanami, T. and Mori, M., 2007. Effects of cadmium administration on reproductive performance of Japanese quail (Coturnix japonica). J. Poult. Sci., 44: 92-97. https://doi.org/10.2141/ jpsa.44.92

Redig, P., Stowe, C., Barnes, D.and Arent, T., 1980. Lead toxicosis in raptors. J. Am. Vet. med. Assoc., 177: 941-943.

Reis, L.S.L.d.S., Pardo, P.E., Camargos, A.S. and Oba, E., 2010. Mineral element and heavy metal poisoning in animals. J. Med. med. Sci., 560-579.

Roberts, T., 1991. The Birds of Pakistan. Vol. II. Printed at Oxford University Press, Karachi.

Roberts, T., 1992a. The birds of Pakistan: Passeriformes. Oxford Univ. Press, Karachi.

Roberts, T.J., 1992b. Birds of Pakistan, The: Passeriformes: Pittas to buntings. Oxford University Press.

Scheuhammer, A. and Templeton, D., 1998. Use of stable isotope ratios to distinguish sources of lead exposure in wild birds. Ecotoxicology, 7: 37-42. https://doi.org/10.1023/A:1008855617453

Scott, D.A., 1989. A directory of Asian wetlands. IUCN, The World Conservation Union.

Shannon, C. and Wiener, W., 1963. The mathematical theory of communication. University of Illinois Press, Urbana.

Steel, R. G. and Torrie, J.H., 1980. Principles and procedures of statistics, a biometrical approach. McGraw-Hill Kogakusha, Ltd.

Stewart, R., 2001. Technical aspects of wetlandswetlands as bird Habitat. National water summary on wetland resources. United States Geological Survey, pp. 86.

Sutherland, W.J., 1996. From individual behaviour to population ecology. Oxford University Press.

Trivedi, P., 1992. Environmental water and soil analysis. Akashdeep Publishing House.

Umar, M., Hussain, M., Murtaza, G., Shaheen, F.A. and Zafar, F., 2018. Ecological concerns of migratory birds in Pakistan: A review. Punjab Univ. J. Zool., 33: 69-76. https://doi.org/10.17582/ pujz/2018.33.1.69.76

WAPDA, P., 2001. Mangla dam raising project. Feasibility Study Report.

Ward, T., Watkins, K. and Southern, L., 1995. Interactive effects of dietary copper, water copper, and Eimeria spp. infection on growth, water intake, and plasma and liver copper concentrations of poults. Poult. Sci., 74: 502-509. https://doi.org/10.3382/ ps.0740502

Weller, M.W., 1999. Wetland birds: habitat resources and conservation implications. Cambridge University Press. https://doi.org/10.1017/ CBO9780511541919

Xie, Z., Sun, Z., Zhang, H. and Zhai, J., 2014. Contamination assessment of arsenic and heavy metals in a typical abandoned estuary wetland, a case study of the Yellow River Delta Natural Reserve. Environ. Monit. Assess., 186: 7211-7232. https://doi.org/10.1007/s10661-014-3922-3

Xu, Y-J., Liu, X-Z. and Ma, A-J., 2004. Current research on toxicity effect and molecular mechanism of heavy metals on fish. Mar. Sci. Qingdao Chinese Ed., 28: 67-70. 